\title{
Cloning and Characterization of a Conjugated Bile Acid Hydrolase Gene from Clostridium perfringens
}

\author{
JAMES P. COLEMAN* AND L. LYNN HUDSON \\ Department of Microbiology and Immunology, School of Medicine, East Carolina University,
} Greenville, North Carolina 27828-4354

Received 30 January 1995/Accepted 2 April 1995

\begin{abstract}
The gene encoding a conjugated bile acid hydrolase (CBAH) from Clostridium perfringens 13 has been cloned and expressed in Escherichia coli, and its nucleotide sequence has been determined. Nucleotide and predicted amino acid sequence analyses indicated that the gene product is related to two previously characterized amidases, a CBAH from Lactobacillus plantarum (40\% identity) and a penicillin $\mathrm{V}$ amidase from Bacillus sphaericus (34\% identity). The product is apparently unrelated to a CBAH from $C$. perfringens for which $\mathrm{N}$-terminal sequence information was determined. The gene product was purified from recombinant $E$. coli and used to raise antibody in rabbits. The presence of the protein in $C$. perfringens was then confirmed by immunoblot analysis. The protein was shown to have a native molecular weight of 147,000 and a subunit molecular weight of 36,100 , indicating its probable existence as a tetramer. Disruption of the chromosomal $C$. perfringens CBAH gene with a chloramphenicol resistance cartridge resulted in a mutant strain which retained partial CBAH activity. Polyacrylamide gel electrophoresis followed by enzymatic activity staining and immunoblotting indicated that the mutant strain no longer expressed the cloned CBAH (CBAH-1) but did express at least one additional CBAH (CBAH-2). CBAH-2 was immunologically distinct from CBAH-1, and its mobility on native polyacrylamide gels was different from that of CBAH-1. Furthermore, comparisons of pH optima and substrate specificities of CBAH activities from recombinant $E$. coli and wild-type and mutant $C$. perfringens provided further evidence for the presence of multiple CBAH activities in $C$. perfringens.
\end{abstract}

Among the many compounds metabolized by the gastrointestinal microflora of mammals are the endogenously produced bile acids. These "biological detergents" are synthesized in the liver from cholesterol and are typically secreted in the form of amino acid conjugates, with an amide bond between the bile acid carboxyl group and the amino group of either glycine or taurine. Once in the intestine, the bile acids may be converted to a number of metabolites by the intestinal microflora. One of the more common reactions, the hydrolysis of the amide linkage, is catalyzed by a class of microbial enzymes referred to collectively as conjugated bile acid hydrolases (CBAH). These enzymes are produced by a number of different bacteria, including, but not limited to, members of the genera Clostridium, Bacteroides, Lactobacillus, Enterococcus, and Bifidobacterium (1, 5, 9, 10, 12-14, 17, 20, 23-26, 33, 42, 43, 45). Because the efficient enterohepatic recirculation of bile acids is partially dependent on their recognition in the conjugated form by active transport sites in the terminal ileum (8, 36), bacterial CBAH may be viewed as being in competition with these active transport sites. Binding of a conjugated bile acid to an active transport site results in its return to the liver, while hydrolysis by bacterial CBAH results in production of a free bile acid which binds with a lower affinity to the transport sites $(36,40)$ and thus may pass into the large intestine or cecum, where further metabolism may occur. The most important metabolic transformation which these free bile acids may undergo is 7-dehydroxylation. This reaction results in the conversion of cholic acid or chenodeoxycholic acid to deoxycholic acid or lithocholic acid, respectively. These last two "secondary" bile acids are more hydrophobic than their parent bile

\footnotetext{
* Corresponding author. Mailing address: Department of Microbiology and Immunology, School of Medicine, East Carolina University, Greenville, NC 27858. Phone: (919) 816-3133. Fax: (919) 816-3535. Electronic mail address: coleman@merlin.med.ecu.edu.
}

acids and have been implicated in a variety of cytotoxic phenomena $(3,30,34,37)$. Because of the important role which $\mathrm{CBAH}$ plays in these subsequent reactions, we are interested in the enzymology and the regulation of CBAH activity.

A CBAH from Clostridium perfringens is available commercially and has been widely used for hydrolysis of conjugated of bile acids preliminary to chemical analysis. Although a $\mathrm{CBAH}$ from $C$. perfringens MCV 815 has been purified and characterized (11), little is known about the enzymology of the reaction or the role the enzyme plays in the growth of the organism in the gastrointestinal tract. The early studies of Nair and coworkers $(27-29,35)$ suggested that there were actually multiple forms of CBAH present in $C$. perfringens on the basis of observations of differential stabilities of activity against different conjugated bile acids substrates. We present in this work a confirmation of this earlier observation of multiple CBAHs in $C$. perfringens and provide the nucleotide sequence and derived amino acid sequence for one CBAH isozyme of $C$. perfringens 13.

\section{MATERIALS AND METHODS}

Bacterial strains, plasmids, and growth conditions. $C$. perfringens 13 was obtained from Edmund Stellwag, Department of Biology, East Carolina University, and was grown on brain heart infusion medium (BHI) under an atmosphere of $\mathrm{CO}_{2}-\mathrm{H}_{2}-\mathrm{N}_{2}(10: 10: 80)$ in a Coy anaerobic chamber at $37^{\circ} \mathrm{C}$. Escherichia coli DH5 $\alpha$ MCR and NM522 were obtained from GIBCO-BRL Life Technologies and were grown aerobically on Luria-Bertani medium on a rotary shaker at $37^{\circ} \mathrm{C}$. pUC18 (BamHI and bacterial alkaline phosphatase digested) and pKK233-2 were obtained from Pharmacia Biotech, Inc., and pHR106 (38) was obtained from Phillip Hylemon, Medical College of Virginia, Virginia Commonwealth University. The following compounds were added to growth media when appropriate at the indicated final concentrations: ampicillin, $100 \mu \mathrm{g} / \mathrm{ml}$; chloramphenicol, $10 \mu \mathrm{g} / \mathrm{ml}$; and isopropyl- $\beta$-D-thiogalactoside (IPTG), $0.2 \mathrm{mM}$.

Recombinant DNA techniques. Plasmid DNA was isolated from E. coli and $C$. perfringens by the alkali lysis procedure (21). Templates for DNA sequencing were purified with Qiagen columns (QIAGEN, Inc., Chatsworth, Calif.). Chromosomal DNA was isolated from $C$. perfringens by the procedure of Marmur (22), with the inclusion of the lysozyme pretreatment. Restriction endonuclease 
digestions were carried out as recommended by the suppliers. Electrophoresis of DNA, ligation reactions, sucrose gradient centrifugation, and other nucleic acid manipulations were performed as described by Maniatis et al. (21).

Plasmid library preparation. Genomic DNA from $C$. perfringens 13 was partially digested and subjected to sucrose density gradient centrifugation as described by Maniatis et al. (21). Fractions containing DNA in the 7-kb size range were pooled, and an aliquot was ligated to Bam HI-digested bacterial alkaline phosphatase-treated pUC18 and transformed into E. coli DH5 $\alpha \mathrm{MCR}$ (Library Efficiency; GIBCO-BRL). Following a 1-h outgrowth period, the cells were spread onto plates containing the differential medium described by Christiaens et al. (6). This medium is a modified Luria-Bertani agar containing additional glucose as well as $0.5 \%$ sodium taurodeoxycholate and is buffered to $\mathrm{pH} 6.0$. Action of $\mathrm{CBAH}$ in this environment causes hydrolysis of the soluble sodium taurodeoxycholate to deoxycholate, which is insoluble at the medium $\mathrm{pH}$ and forms a white precipitate. After 12 to $24 \mathrm{~h}$, plates were observed for colonies with precipitated deoxycholate halos. These were picked and restreaked to purity.

DNA sequencing. DNA was sequenced by the dideoxynucleotide chain-terminating method (39) with alkali-denatured double-stranded plasmid templates, according to the procedure supplied with the Sequenase version 2.0 sequencing reagent kit (U.S. Biochemical). Labeling reactions were performed with $\left[\alpha-{ }^{35}\right.$ S]ATP (1325 Ci/mmol; New England Nuclear). Universal M13/pUC forward and reverse primers were used for sequencing those regions flanking vector sequences, while internal regions were sequenced with specific primers based on observed DNA sequences. All primers were synthesized by the DNA Synthesis Core Laboratory, School of Medicine, East Carolina University.

Analysis of sequence data. Nucleic acid and protein sequence analyses were performed with the GCG Sequence Analysis Software Package (Genetics Computer Group, Inc., Madison, Wis.). Sequence information was submitted to GenBank using AUTHORIN (Intelligenetics, Inc., Mountain View, Calif.).

Disruption of CBAH gene in $\boldsymbol{C}$. perfringens. The clostridial chloramphenicol acetyltransferase (CAT) gene contained on plasmid pHR106 (38) was excised by digestion with EcoRI and HindIII. After the ends were blunted by treatment with Klenow fragment, the CAT gene was ligated to a derivative of the original CBAH-pUC18 recombinant plasmid. This derivative was generated by exonuclease III deletion of the upstream sequence to within $68 \mathrm{bp}$ of the translational start site, followed by digestion with $\mathrm{XbaI}$ and $\mathrm{SmaI}$. The resulting CBAH-CAT construct consisted of $679 \mathrm{bp}$ of the N-terminal portion of the CBAH reading frame (approximately two-thirds of the total), followed by the CAT gene, followed by vector sequence. Since the pUC replicon is not active in $C$. perfringens 13 , this construct was designed to disrupt the $C$. perfringens $\mathrm{CBAH}$ gene via chromosomal recombination. The plasmid was introduced into $C$. perfringens by electroporation. Cells were prepared by growing them anaerobically in BHI to the mid-logarithmic phase of growth. After the cells had been harvested by centrifugation at $6,000 \times g$ for $15 \mathrm{~min}$, they were washed twice in ice-cold $2.5 \mathrm{mM}$ sodium phosphate-10\% (vol/vol) polyethylene glycol ( $\mathrm{pH} 6.5)$ and resuspended in $0.02 \times$ the original culture volume of this same buffer. Cell suspensions (120 $\mu \mathrm{l})$ containing 1 to $5 \mu \mathrm{g}$ of plasmid were electroporated at $5,000 \mathrm{~V} / \mathrm{cm}$ with a Bio-Rad Gene Pulser with Pulse Controller (0.2-cm cuvettes, 1,000 V, $25 \mu \mathrm{F}$, infinite resistance setting). They were then immediately transferred to $5 \mathrm{ml}$ of $\mathrm{BHI}$ and incubated anaerobically at $37^{\circ} \mathrm{C}$ for $3 \mathrm{~h}$ before aliquots were plated on $\mathrm{BHI}$ agar plates containing $10 \mu \mathrm{g}$ of chloramphenicol per ml. Chloramphenicolresistant colonies were restreaked to purity before large-scale liquid cultures were grown. These cultures were used for protein and enzyme analysis, as well as for DNA analysis to verify the presence of the CAT gene and altered CBAH gene by restriction enzyme digestion and Southern blot analysis.

Protein and enzyme assays. Protein was assayed by the dye-binding method of Bradford (4) with bovine serum albumin as the standard with commercially available reagents (Bio-Rad Laboratories). Conjugated bile acid hydrolase activity was assayed colorimetrically by measuring the amount of taurine liberated after a fixed period at $37^{\circ} \mathrm{C}$. The standard assay was performed in $1.5-\mathrm{ml}$ microcentrifuge tubes; the assay mixture contained, in a final volume of $0.5 \mathrm{ml}, 25$ $\mu \mathrm{mol}$ of sodium acetate ( $\mathrm{pH} 5.5$ ), $0.5 \mu \mathrm{mol}$ of dithiothreitol, $0.5 \mu \mathrm{mol}$ of EDTA, $1 \mu \mathrm{mol}$ of sodium taurocholate, and enzyme. Reactions were initiated by the addition of the sodium taurocholate after a 5-min equilibration at $37^{\circ} \mathrm{C}$. After 5 $\mathrm{min}$, the reaction was stopped by addition of an equal volume of $20 \%$ (wt/vol) trichloroacetic acid. After centrifugation for $5 \mathrm{~min}$ to remove precipitated protein, $100 \mu \mathrm{l}$ of the mixture was assayed for free amino groups by the ninhydrin reaction, using the procedure described by Lee and Takahashi (16). One unit of activity is defined as that amount which catalyzes the liberation of $1 \mu \mathrm{mol}$ of taurine in $1 \mathrm{~min}$ under the conditions described above. To determine the effect of buffer $\mathrm{pH}$ on enzymatic activity while avoiding the possibility of buffer-specific reaction differences, a mixed-buffer system was used. A stock $2 \times$ buffer which contained $30 \mathrm{mM}$ citric acid, $30 \mathrm{mM}$ boric acid, and $30 \mathrm{mM}$ monobasic potassium phosphate was prepared. The $\mathrm{pH}$ of the buffer was adjusted to various points from 2.5 to 9.0 in $0.5 \mathrm{pH}$ unit increments with sodium hydroxide. Each of these buffer stocks was used in place of the sodium acetate component in the standard assay described above. The CBAH activity in chromatography fractions during purification was monitored by a precipitation assay. Assays were performed in round-bottom 96-well microtiter plates. Aliquots (1 to $20 \mu \mathrm{l})$ of fractions were added to individual wells containing $100 \mu \mathrm{l}$ of reaction cocktail $(50 \mathrm{mM}$ sodium phosphate [pH 6.0], $10 \mathrm{mM}$ 2-mercaptoethanol, $1 \mathrm{mM}$ EDTA, $10 \mathrm{mM}$ sodium taurodeoxycholate). Samples containing $\mathrm{CBAH}$ activity generate free deoxy- cholate, which is insoluble at the reaction $\mathrm{pH}$. This is easily visualized as a white precipitate after approximately $15 \mathrm{~min}$ in samples with high activity. The length of time required to form visible precipitate corresponds roughly to the level of activity in the fraction. By scoring plates for activity every $5 \mathrm{~min}$, the relative activity present in different fractions can be estimated very accurately.

Preparation of $C$. perfringens and $E$. coli cell extracts and purification of CBAH from $E$. coli. All steps were performed at $4^{\circ} \mathrm{C}$, except for column chromatographies, which were performed at $25^{\circ} \mathrm{C}$. E. coli NM522 containing plasmid with the CBAH gene downstream from the trp-lac promoter (see Results) was grown from a $5 \%$ inoculum with overnight cultures in Luria-Bertani medium containing $100 \mu \mathrm{g}$ of ampicillin per $\mathrm{ml}$ and $0.2 \mathrm{mM}$ IPTG. Cells were harvested in the early stationary phase of growth (approximately $7 \mathrm{~h}$ after inoculation) by centrifugation and resuspended in 3 volumes of $20 \mathrm{mM}$ sodium phosphate-10 $\mathrm{mM} 2$-mercaptoethanol-1 mM EDTA (pH 7.0) (buffer A). The suspension was lysed by two passages through a French pressure cell $\left(14,000 \mathrm{lb} / \mathrm{in}^{2}\right)$ and centrifuged at 17,000 $\times g$ for $45 \mathrm{~min}$ to remove debris and unbroken cells. The supernatant was adjusted to a protein concentration of approximately $20 \mathrm{mg} / \mathrm{ml}$, brought to $50 \%$ saturation with solid ammonium sulfate, equilibrated for $30 \mathrm{~min}$ at $4^{\circ} \mathrm{C}$, and then centrifuged at $14,000 \times g$ for $30 \mathrm{~min}$. The pellet was suspended in $0.5 \times$ the original volume in buffer A containing $0.5 \mathrm{M}$ ammonium sulfate $(\mathrm{pH} 6.0)$ (buffer $\mathrm{P}$ ). Following centrifugation at $5,000 \times \mathrm{g}$ for $15 \mathrm{~min}$ to remove insoluble material, the solution was applied to a phenyl-Sepharose CL-4B column ( 2.5 by 9.0 $\mathrm{cm}$ ) equilibrated with buffer P. After the column was washed with buffer P until the effluent $A_{280}$ returned to baseline, CBAH was eluted with a linear decreasing salt gradient ( 0.6 to $0 \mathrm{M}$ ammonium sulfate in $20 \mathrm{mM}$ sodium phosphate- $10 \mathrm{mM}$ 2-mercaptoethanol [pH 7.0]). Active fractions (as assayed by the 96-well plate precipitation method) were combined and applied to a Q Sepharose Fast Flow column equilibrated with $20 \mathrm{mM}$ sodium phosphate-10 mM 2-mercaptoethanol-5\% glycerol ( $\mathrm{pH} 7.0$ ) (buffer Q). After the column was washed with buffer Q until the effluent $A_{280}$ had returned to baseline, CBAH was eluted with a 0 to 0.5 $\mathrm{M} \mathrm{NaCl}$ gradient in buffer $\mathrm{Q}(200 \mathrm{ml}$ total volume). Active fractions were combined, concentrated by ultrafiltration through an Amicon YM-10 membrane, and stored at $-20^{\circ} \mathrm{C}$. Extracts from $C$. perfringens 13 (wild type and mutant) were prepared by growing cells in BHI to either mid-logarithmic phase or late stationary phase. The harvested cell pellets were suspended in 3 volumes of buffer A and disrupted by two passages through a French pressure cell. Following centrifugation at $17,000 \times g$ for $45 \mathrm{~min}$, the supernatant was dialyzed overnight against buffer $\mathrm{A}$ and used without further purification for enzyme assays and polyacrylamide gel electrophoresis (PAGE) analyses.

Production of antibody. Antibodies to $\mathrm{CBAH}$ were produced in the laboratory of Mason Smith, School of Medicine, East Carolina University. CBAH purified from $E$. coli was used to raise antibody in a female New Zealand White rabbit. Following an initial injection in Freund's complete adjuvant, booster injections were given in Freund's incomplete adjuvant. Serum from test bleeds was assayed by Western blot (immunoblot) analysis to determine reactivity and specificity. Following final bleeding by cardiac puncture, serum was allowed to clot at room temperature for $2 \mathrm{~h}$ and centrifuged. The supernatant was stored overnight at $4^{\circ} \mathrm{C}$ and recentrifuged to remove additional precipitate. Immunoglobulins were then enriched by ammonium sulfate precipitation as described by Ausubel et al. (2). Nonspecific antibodies to $E$. coli proteins were removed by treatment of aliquots of the antibody solution with crude extracts prepared from $E$. coli NM522 coupled to Sepharose (Affi-Gel 15; Bio-Rad), as described by Maniatis et al. (21). Coupling of protein to the Affi-Gel was performed as specified by the manufacturer.

Protein electrophoresis and immunoblotting. Sodium dodecyl sulfate (SDS)PAGE was carried out in 0.75 -mm-thick gradient gels ( 7 to $20 \%$ total acrylamide [T], $2.7 \%$ cross-linker [C]), using the discontinuous buffer system of Laemmli (15). High- and low-molecular-weight protein standards (Bio-Rad Laboratories) or 10-kDa molecular mass markers (GIBCO-BRL) were used as size markers Following electrophoresis, proteins were stained with $0.03 \%(\mathrm{wt} / \mathrm{vol})$ Coomassie brilliant blue R-250 in $15 \%$ (vol/vol) methanol-10\% (vol/vol) acetic acid. Native gel electrophoresis was carried out in $1.5-\mathrm{mm}$ gradient gels ( 5 to $15 \% \mathrm{~T}, 2.7 \% \mathrm{C}$ ) with the Laemmli buffer system, omitting the SDS and including $5 \mathrm{mM}$ sodium thioglycolate. Electrophoresis was conducted at $4^{\circ} \mathrm{C}$ at $150 \mathrm{~V}$ (constant voltage) until the bromphenol blue tracking dye reached the bottom of the gel. CBAH activity was detected by first washing the gel twice for $15 \mathrm{~min}$ each in $250 \mathrm{ml}$ of $0.5 \mathrm{M}$ sodium acetate- $10 \mathrm{mM} 2$-mercaptoethanol-1 mM EDTA $(\mathrm{pH} 5.5)$ at $10^{\circ} \mathrm{C}$ and then incubating the gel at $37^{\circ} \mathrm{C}$ in $50 \mathrm{ml}$ of $0.5 \mathrm{M}$ sodium phosphate $(\mathrm{pH}$ 5.5)-10 mM 2-mercaptoethanol-10 mM sodium taurodeoxycholate. Within $1 \mathrm{~h}$, $\mathrm{CBAH}$ activity in the gel resulted in the formation of a white precipitate of deoxycholic acid at the position of the enzyme. The gels were then photographed under tungsten light on a glossy black background with Polaroid Type 55 film. The negative was then rephotographed to produce the negative image shown in this work. Control gels were incubated with the reaction buffer lacking taurodeoxycholate to ensure that observed bands were not due to acid denaturation and precipitation of proteins. For Western analyses, proteins were electrotransferred to nitrocellulose membranes immediately following electrophoresis. The methanol-Tris-glycine transfer buffer of Towbin et al. (46) was used for both SDScontaining and native gels; however, native gels were incubated at $37^{\circ} \mathrm{C}$ for 30 min in Laemmli tank buffer containing 0.5\% SDS prior to electrotransfer to facilitate the migration of proteins from the gel. Following incubation with the NM522 extract-absorbed antiserum to $\mathrm{CBAH}$, membranes were incubated with 


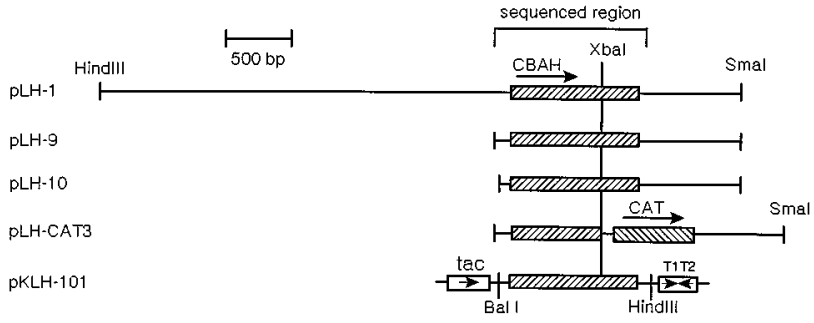

FIG. 1. Relationships between pLH-1 and derivatives. The originally cloned fragments and four derivatives referred to in the text are shown. All members of the pLH series are inserts in pUC-18, while pKLH-101 is derived from the expression vector pKK233-2. The arrows above the CBAH and CAT genes indicate the direction of transcription and translation. The arrow within the tac promoter box indicates the orientation for transcript initiation. The downstream terminator of pKK233-2 (T1T2) is indicated by the opposing arrows within the boxed region. The bracket at the top of the figure indicates the region for which the nucleotide sequence is reported in this work. This region was sequenced in both strands over its entirety.

horseradish peroxidase-conjugated goat anti-rabbit immunoglobulin G. Detection was then performed with 4-chloro-1-naphthol reagent.

Determination of native molecular weight. CBAH purified from recombinant E. coli as described above was chromatographed on a Sephacryl S-200 column $(2.5$ by $95 \mathrm{~cm}$ ) equilibrated with $20 \mathrm{mM}$ sodium phosphate $(\mathrm{pH} 7.0), 100 \mathrm{mM}$ sodium chloride, and $10 \mathrm{mM} 2$-mercaptoethanol. The peak fractions were identified by measuring enzymatic activity in the 96-well plate assay. The column was calibrated with cytochrome $c(12.4 \mathrm{kDa})$, carbonic anhydrase $(29 \mathrm{kDa})$, bovine serum albumin $(66 \mathrm{kDa})$, yeast alcohol dehydrogenase $(150 \mathrm{kDa})$, and sweet potato $\beta$-amylase $(200 \mathrm{kDa})$.

Nucleotide sequence accession number. The nucleotide sequence of the DNA fragment containing the CBAH gene has been submitted to GenBank with the accession number U20191.

\section{RESULTS}

Identification and subcloning of the CBAH gene. A genomic library of $C$. perfringens 13 was constructed by ligation of strain 13 DNA which had been partially digested with MboI-toBamHI-digested, phosphatase-treated pUC18. Following transformation into E. coli $\mathrm{DH} 5 \alpha \mathrm{MCR}$ and plating on differential medium (6), 1 colony from the approximately 3,000 total screened produced a halo of precipitate. This colony was streaked to purity, plasmid was isolated, and crude extracts were prepared and subjected to enzymatic analysis. Plasmid isolates were shown to contain a 5,000-bp insert in pUC18 and were designated pLH-1. Enzymatic analyses of crude extracts verified that the strain was catalyzing the hydrolysis of taurodeoxycholate. Restriction mapping and exonuclease III deletion analyses were performed to localize the CBAH gene on this fragment. The restriction map and relationship of various subclones to the parent fragment are depicted in Fig. 1. Deletions from the HindIII end of the multiple cloning region into the insert retained $\mathrm{CBAH}$ activity down to an insert size of approximately $1,900 \mathrm{bp}$. Two of these deletion plasmids, differing in length by $36 \mathrm{bp}$, were used for the majority of the sequencing, mutagenesis, and $E$. coli expression studies and are designated pLH-9 and pLH-10. Additional deletions extending further into the insert were used for DNA sequencing purposes.

Nucleotide and amino acid sequence analysis. The region of pLH-9 proximal to the HindIII side of the pUC18 multiple cloning region, as well as more extensive exonuclease III-deleted inserts, were subjected to chain-terminating nucleotide sequence analysis of both strands (Fig. 2). The resulting 1,087 bp of sequence information revealed a 990-bp open reading frame (bases 69 to 1058), with a coding potential for a 329residue polypeptide $(37,185 \mathrm{Da})$. The base composition of the open reading frame $(27.5 \% \mathrm{G}+\mathrm{C})$ is consistent with a clostridial origin. A potential Shine-Dalgarno sequence was found with a spacing of 11 bases to the putative start codon. A protein database search revealed that the hypothetical polypeptide (CPE13-A) is related to a CBAH from Lactobacillus plantarum (LPL; $39.8 \%$ identity) (6), as well as to the penicillin $\mathrm{V}$ amidase from Bacillus sphaericus (BSPPVA; 34.2\% identity) (31) (Fig. 3). Also included in the sequence comparison are the sequences of N-terminal peptides determined from the CBAHs purified from $C$. perfringens MCV 815 (CPE815) (11) and from Lactobacillus sp. strain 100-100 (LSP100-A) (18). While the two Lactobacillus sequences had 13 identical amino acids over a stretch of 25 residues at the $\mathrm{N}$ terminus, there was little sequence homology between the CBAHs from the two $C$. perfringens strains (three matches over 13 residues, including the N-terminal methionine). Although no definitive conclusions should be drawn from comparisons within such a small region, this does suggest that there may be fundamental differences between the two $C$. perfringens enzymes. Also indicated in Fig. 3 are residues which are conserved throughout all three of the proteins whose complete predicted sequence is shown. Several highly conserved regions are notable. Protein database searches with these short peptide sequences provided no information pointing to additional relatives to this cluster.

Expression and purification of CBAH from E. coli. To confirm the existence of a protein corresponding to the cloned $\mathrm{CBAH}$ in the parent organism, we used immunoblot analyses. For this purpose, it was necessary to purify sufficient amounts of protein from recombinant $E$. coli for antibody preparation. Expression was maximized by subcloning the $\mathrm{CBAH}$ reading frame, along with the Shine-Dalgarno sequence, into a position downstream from the trp-lac promoter of the expression vector pKK223-3. This was facilitated by PCR amplification of the cloned fragment with primers engineered to contain a BalI site ( $5^{\prime}$ end) and a HindIII site ( $3^{\prime}$ end) (Fig. 2). After digestion of the amplification reaction mixture with these two enzymes and gel purification, the fragment was ligated to pKK223-3 prepared by digestion with NcoI (promoter proximal) and filling in protruding ends with Klenow fragment, followed by digestion with HindIII (promoter distal). The resulting construct, pKLH101, when transformed into $E$. coli NM522, produced high levels of $\mathrm{CBAH}$ activity in response to the presence of IPTG $(0.2 \mathrm{mM})$ in the growth medium. The enzyme from $E$. coli NM522(pKLH-101) cultures induced with IPTG was purified by a combination of ammonium sulfate fractionation, hydrophobic interaction chromatography (Phenyl Sepharose CL-4B), and anion-exchange chromatography (Q Sepharose Fast Flow). The results of a typical purification from $7 \mathrm{~g}$ (wet weight) of cells ( 2 liters of culture) are summarized in Table 1 . Approximately 200 to $300 \mu \mathrm{g}$ of this material was used to raise rabbit antibody. The remainder was used for physical and biochemical characterization.

Native and subunit size of CBAH. Chromatography of purified CBAH-1 on a calibrated Sephacryl S-200 column provided a native molecular weight estimation of 147,000 (data not shown). SDS-PAGE analysis of purified CBAH-1 indicated a single polypeptide with molecular weight of 36,100. This correlates well with the calculated molecular weight based on analysis of the open reading frame (i.e., 37,185). Together, these data suggest that the enzyme exists in its native state as a tetramer.

Insertional mutagenesis of CBAH gene in $C$. perfringens 13. The gene in $C$. perfringens corresponding to the cloned CBAH gene was disrupted by insertional mutagenesis with a suicide vector (pLH-CAT3) based on pUC8 and containing an $\mathrm{N}$ terminal portion of the CBAH gene upstream from the clos- 


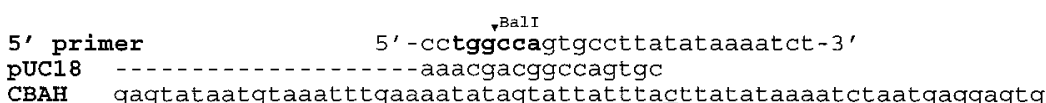

gtgttlatgtgtacaggattagccttagaaacaaaagatggattacatttgtttggaaga MetCysThrGlyLeuAlaLeuGluThrLysAspGlyLeuHisLeuPheGlyArg

aatatggatattgaatattcatttaatcaatctattatatttattcctaggaattttaa AsnMetAspIleGluTyrSerPheAsnGlnSerI leIlePheIleProArgAsnPheLys

tgtgtaaacaaatcaaacaaaaagaattaacaacaaatatgctgttcttggaatggga CysValAsnLysSerAsnLysLysGluLeuThrThrLysTyrAlaValLeuGlyMetGly

actattttgatgattatcctacctttgcagatggtatgaatgaaaagggattagggtgt Thr. IePheAspAspTyrProThrFheAlaAspGlyMetAsnGluLysGlyLeuGlyCys

gctggcttaaatttccctgttatgttagctattctaagaagatatagaaggtaaaact AlaGlyLeuAsnPheProValTyrValserTyrSerLysGluAspIleGluGlyLysThr

aatatccagtatataatttctattatgggttttagctaattttagctcagtagaagag AsnIleProValTyrAsnPheLeuLeuTrpVal LeuAlaAsnPheSerSerValGluGlu

gtaaaggaagcattaaaaatgctaatatagtggatatacctattagcgaaaatattcct ValLysGluAlaLeuLysAsnAlaAsnIleValAspI leProIleSerGluAsnI lePro

aatacaactcttcattggatgataagcgatataacaggaaagtctattgtggttgaacaa AsnThrThrLeuHisTrpMet IleSerAspIleThrGlyLysSerIleValValGluGln

acaaaggaaaaat taaatgtatetgataataatattggagtattaactaattcacctact ThrLysGluLysLeuAsnVal PheAspAsnAsnIleGlyValLeuThrAsnSerProThr

tttgattggcatgtagcaaattaaatcaatatgtaggtttgagatataatcaagttcca PheAspTroHisValAlaAsnLeuAsnGlnTyrValGlyLeuArgTyrAsnglnVal Pro

gaatttaagttaggagatcaatcttaactgctttaggtcaaggaactggtttagtagga GluPheLYsLeuGIYAspGlnSerLeuThrAlaLeuGlyGlnGlyThrGlyLeuValGly ttaccaggggactttacacctgcatctagatt tataagagtagcatttt taagagatgca LeuProGlyAspPheThrProAlaSerArgPheIleArgValAlaPheLeuArgAspAla

atgataaaaatgataaagattcaatagacttaattgaattttccatatattaaataat MetIleLysAsnAspLysAspSerIleAspLeuIleGluPhePheHis IleLeuAsnAsn

gttgctatggtaagaggatcaactagaactgtagaagaaaaaagtgatcttactcaatat ValAlaMetValArgGlySerThrArgThrValGluGluLys SerAspLeuThrGlnTyr

acaagttgcatgtgtttagaaaaaggaatttattattataatacctatgaaaataatcaa ThrSerCysMetCysLeuGluLysGlyIleTyrTyrTyrAsnThrTyrGluAsnAsngln

attaatgcaatagacatgaataaagaaaacttagatggaaatgaaattaaaacatataaa IleAsnAlaIl eAspMetAsn LysGluAsnLeuAspGIYAsnGluI leLysThrTyrLys

tacaacaaaactttaagtattaatcatgtaaattagtttgttgcatgggcgtgtatcaaa TyrAsnLysThrLeuSerIleAsnHisValAsnEnd $\quad 3^{\prime}$-cgtacccgcacatagt t

actt-3, 1087

cgaaacc-5' 3' primer

62

122

182

242

302

362

422

482

542

602

662

722

FIG. 2. Nucleotide sequence of CBAH gene. The sequence represents the $5^{\prime}$-proximal region of pLH-9. The 5' end of pLH-10 is at residue 37 ( $\left.\mathbf{\nabla}\right)$. The deduced amino acid sequence is shown below the nucleotide sequence. A putative ribosome-binding region is underlined. The two oligonucleotide sequences used to amplify the CBAH gene for overexpression in E. coli are shown at the $5^{\prime}$ and $3^{\prime}$ ends, along with the position of the BalI and HindIII sites contained within them. The sequence of pUC18 which adjoins the $5^{\prime}$ end of the $\mathrm{CBAH}$ gene in $\mathrm{pLH}-10$ is shown between the $\mathrm{CBAH}$ gene and the $5^{\prime}$ amplification primer. The $X b a \mathrm{I}$ cleavage site at residue 748 represents the $3^{\prime}$ end of the CBAH derivative used for mutagenesis, after the introduction of the CAT gene between this position and the HindIII site of pUC18.

tridial CAT gene of pHR106 (Fig. 1). Thus, following electroporation of pLH-CAT3 into C. perfringens 13 , the presence of chloramphenicol-resistant colonies is indicative of recombination of the plasmid into the chromosome. This would most probably be directed by the homology between the chromosomal CBAH gene and the fragment of the same gene present on the plasmid. Southern blot analysis of DNA isolated from several chloramphenicol-resistant colonies with a CBAH genespecific probe revealed a band shift relative to the wild-type DNA, indicating that the recombinational event had taken place within the CBAH gene (data not shown). One of these mutants was chosen for enzymatic analyses and was designated $C$. perfringens 13-3. It was grown in the presence of chloramphenicol at all times because of the potential instability of this single-crossover type of insertional mutation.
CBAH expression in bacterial extracts. CBAH assays (ninhydrin method) were performed on extracts prepared from $E$. coli NM522, DH5 $\alpha$ MCR(pLH-1), and NM522(pKLH-101) and $C$. perfringens 13 and 13-3. The results are shown in Table 2. Strain NM522(pKLH-101) (IPTG induced) expressed CBAH at levels approximately 25-fold higher than did DH5 $\alpha$ MCR(pLH-1) and 180-fold higher than did C. perfringens 13. The putative insertional mutant, strain 13-3, continued to express CBAH activity at $86 \%$ of wild-type levels. This result suggested either that the CBAH-1 gene had not been inactivated completely or that other CBAH enzymes were present, with our enzyme, hereafter designated CBAH-1, making up only a small fraction (14\%) of the total CBAH activity.

SDS-PAGE fractionation followed by Western blot analysis of crude extracts prepared from wild-type strain 13, mutant 


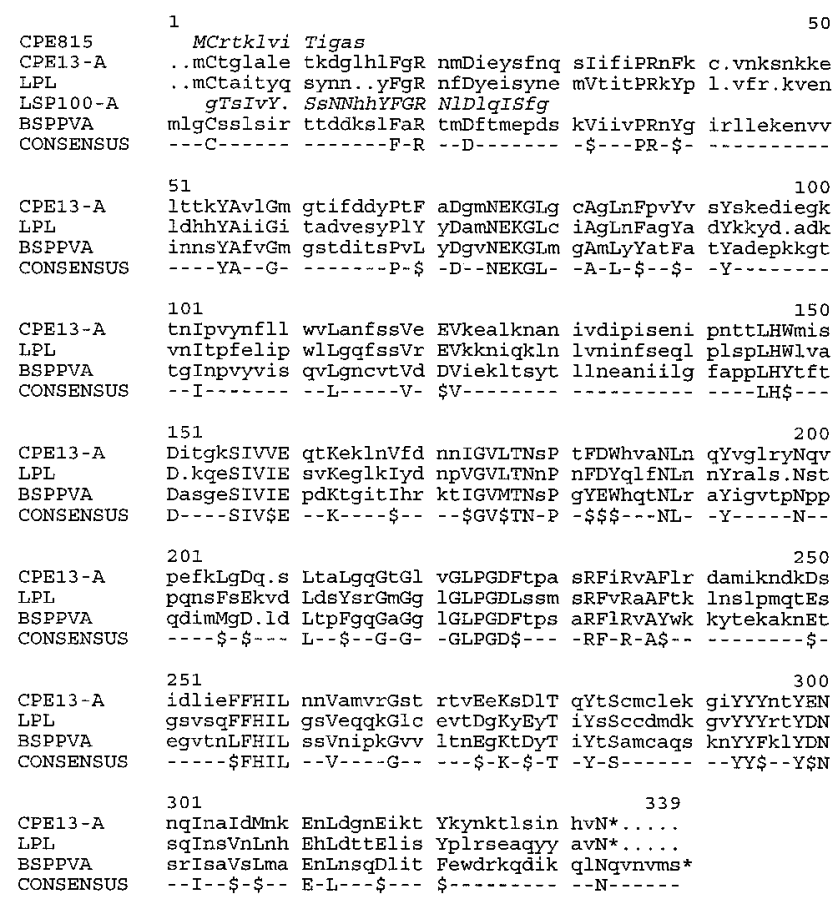

FIG. 3. Amino acid sequence comparisons of the CBAH-PVA group. The entire amino acid sequences (based on nucleotide sequence data) for the CBAH from $C$. perfringens (CPE13-A; this work), the CBAH from $L$. plantarum (LPL) (6), and the penicillin V amidase from Bacillus sphaericus (BSPPVA) (32) are shown, along with the N-terminal sequences (italicized) of the CBAH from $C$. perfringens MCV 815 (CPE815) (11) and the $\alpha$ polypeptide of the CBAH-A from Lactobacillus sp. strain 100-100 (LSP100-A) (19). For the three entire sequences, conserved amino acids are shown in capital letters. Shown below them is the consensus sequence, with those residues identical in all three proteins indicated in capital letters and those positions with conserved but nonidentical residues indicated by the $\$$. For the two $\mathrm{N}$-terminal peptides, the capital letters designate positions where there is identity with the protein from the related organism (i.e., CPE815 versus CPE13-A and LSP100-A versus LPL).

strain 13-3, and E. coli NM522 with and without pKLH-101 indicated that CBAH-1 (37-kDa polypeptide) was present only in wild-type strain 13 and in E. coli NM522 carrying the CBAH-1 gene on the expression vector (Fig. 4A and B). No immunoreactive bands corresponding to the position of CBAH-1 were observed in C. perfringens 13-3 or E. coli NM522 lacking the CBAH gene, nor were new bands at different positions observed. The intensity of the CBAH-1 band in $C$. perfringens 13 extracts did not change in log-phase versus stationary-phase cells, indicating that the protein was produced constitutively throughout the growth cycle.

Native gel electrophoresis followed by CBAH activity stain-

TABLE 1. Typical purification of cloned CBAH from E. coli

\begin{tabular}{lccccc}
\hline \multicolumn{1}{c}{ Purification step } & $\begin{array}{c}\text { Total } \\
\text { amt of } \\
\text { protein } \\
(\mathrm{mg})\end{array}$ & $\begin{array}{c}\text { Total } \\
\text { activity } \\
(\mathrm{U})^{\mathrm{a}}\end{array}$ & $\begin{array}{c}\text { Sp act } \\
(\mathrm{U} / \mathrm{mg})\end{array}$ & $\begin{array}{c}\text { Purifi- } \\
\text { cation } \\
(\text { fold })\end{array}$ & $\begin{array}{c}\text { Yield } \\
(\%)\end{array}$ \\
\hline $\begin{array}{l}\text { Crude extract } \\
\text { 0 to 50\% ammonium } \\
\quad\end{array}$ & 251 & 96 & 0.38 & 1 & 100 \\
$\begin{array}{l}\text { sulfate } \\
\begin{array}{l}\text { Phyl-Sepharose CL- } \\
\text { 4B }\end{array}\end{array}$ & 23 & 50 & 0.61 & 1.6 & 90 \\
Q Sepharose Fast Flow & 0.9 & 29 & 32.22 & 84.8 & 30 \\
\hline
\end{tabular}

${ }^{a}$ One unit is that amount of enzyme releasing $1 \mu \mathrm{mol}$ of taurine per min under the assay conditions described in Materials and Methods.
TABLE 2. Properties of CBAH activity from various extracts

\begin{tabular}{|c|c|c|c|c|}
\hline Source & Sp act ${ }^{a}$ & $\begin{array}{l}\text { Relative } \\
\text { activity }^{b}\end{array}$ & $\begin{array}{c}\mathrm{T} / \mathrm{G} \\
\text { ratio }^{c}\end{array}$ & $\begin{array}{c}\mathrm{pH} \\
\text { optimum }\end{array}$ \\
\hline C. perfringens 13 & $2.12 \times 10^{-3}$ & 1.00 & 0.52 & 4.5 \\
\hline C. perfringens $13-3$ & $1.82 \times 10^{-3}$ & 0.86 & 0.32 & 4.5 \\
\hline E. coli NM522 & $\mathrm{ND}^{d}$ & 0 & & \\
\hline E. coli $\mathrm{DH} 5 \alpha \mathrm{MCR}(\mathrm{pLH}-1)$ & $1.45 \times 10^{-2}$ & 6.84 & $\mathrm{NT}^{e}$ & NT \\
\hline E. coli NM522(pKLH-101) & $3.80 \times 10^{-1}$ & 179 & 1.33 & 5.5 \\
\hline $\begin{array}{l}\text { Cholylglycine hydrolase } \\
\text { (Sigma Chemical Co.) }\end{array}$ & NT & & 0.38 & 4.5 \\
\hline
\end{tabular}

${ }^{a}$ Micromoles of taurine formed per minute per milligram of protein

${ }^{b}$ Specific activity relative to that of $C$. perfringens 13 .

${ }^{c} \mathrm{~T} / \mathrm{G}$ ratio, activity on taurocholate/activity on glycocholate.

${ }^{d} \mathrm{ND}$, no activity detected.

${ }^{e} \mathrm{NT}$, not tested.

ing clearly demonstrates the presence of an additional $\mathrm{CBAH}$ (CBAH-2) in wild-type strain 13 and mutant strain 13-3 (Fig. 4C). Western blot analyses of parallel gels show that CBAH-2 is not immuno-cross-reactive with CBAH-1 (Fig. 4D). It should be noted that the activities of $\mathrm{CBAH}-1$ and $\mathrm{CBAH}-2$ displayed differential stabilities to the activity staining procedure. Thus, the band intensity observed in Fig. 4C does not necessarily reflect the amount of enzyme present and should be interpreted only qualitatively.

Substrate specificity of CBAHs. The dissimilarity of CBAH-1 and CBAH-2 was apparent after substrate specificity analyses (Table 2). This property is demonstrated best by analyzing the $\mathrm{T} / \mathrm{G}$ ratio, defined as the ratio of the hydrolysis rate for taurocholic acid to that for glycocholic acid. CBAH-1 assays performed with crude protein extracts from recombinant $E$. coli hydrolyzed taurocholate at a higher rate than glycocholate $(\mathrm{T} / \mathrm{G}$ ratio, 1.33$)$, while extracts from wild-type strain 13, mutant strain 13-3, and the commercially available enzyme preparation gave $\mathrm{T} / \mathrm{G}$ ratios of $0.57,0.32$, and 0.38 , respectively. The higher $\mathrm{T} / \mathrm{G}$ activity ratio of extracts containing the cloned gene product relative to strain 13 extracts illustrates its difference from the major $\mathrm{CBAH}$ activity of strain 13 . The lower ratio in the mutant strain $13-3$ versus the wild type is consistent with the loss of a CBAH activity with preference for taurine-conjugated bile acids (CBAH-1) from a mixture of CBAHs with overall preference for glycine conjugates.

pH optima for CBAH activities. Differences among the various extracts were also apparent with regard to $\mathrm{pH}$-activity profiles, and these are summarized in Table 2. The optimum for activities of CBAH from extracts of strains 13 and 13-3, as well as commercial cholylglycine hydrolase (Sigma), was $\mathrm{pH}$ 4.5. However, the activity expressed in extracts from E. coli NM522(pKLH-101) had an optimum at pH 5.5.

\section{DISCUSSION}

The heterogeneity of CBAH among different genera of bacteria became apparent once the characterization of several of these enzymes from different sources had been reported (11, $14,28,44)$. The major differences which have been observed are in substrate specificity and molecular weight. The enzyme from Bacteroides vulgatus was shown to preferentially hydrolyze taurine-conjugated bile acids (14), while those from two Lactobacillus species $(6,18), C$. perfringens $(11,28)$, and Bacteroides fragilis (44) were generally more active on glycine conjugates, with the degree of difference in hydrolysis rates varying with the source organism as well as the bile acid moiety. In addition, earlier studies by Mitvedt and Norman (25) with bacterial cultures pointed to a diversity of enzymes. Some 
A

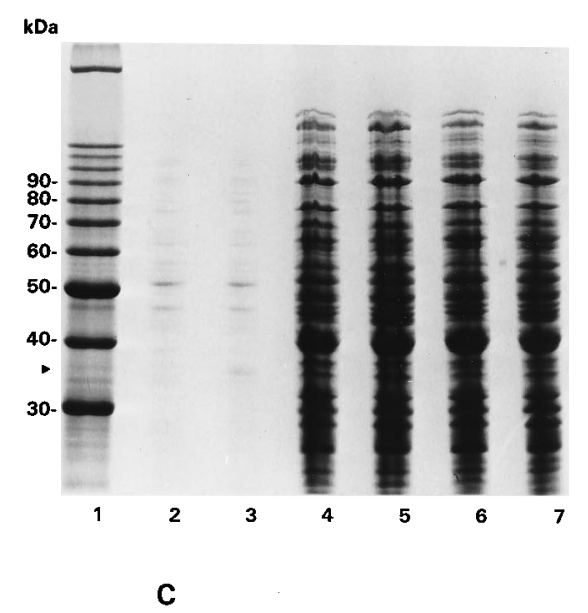

B

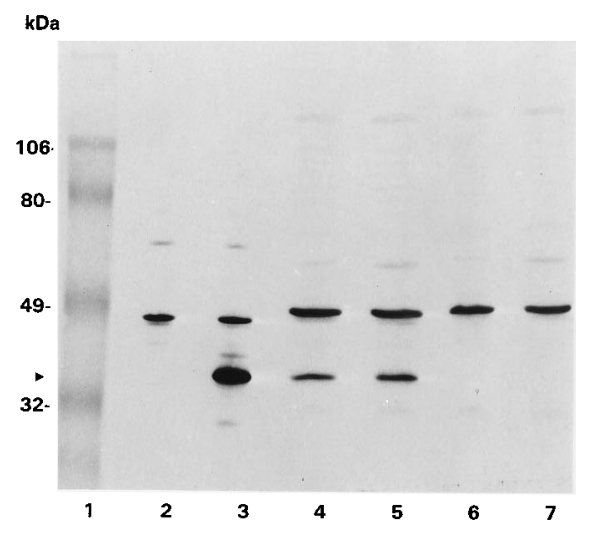

D

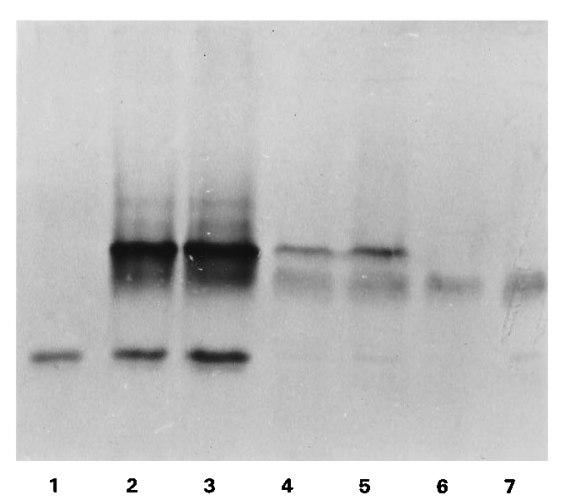

FIG. 4. SDS-PAGE and native PAGE analyses of CBAHs. (A) Coomassie blue stain of proteins separated on SDS-PAGE gels (0.75 mm; total acrylamide [T], $10 \%$; cross-linker [C], 2.7\%). Lanes: 1, 10-kDa marker; 2, NM522 (1 $\mu \mathrm{g})$; 3, NM522(pKLH-101) $(1 \mu \mathrm{g})$; 4, strain 13, log phase (50 $\mu \mathrm{g}) ; 5$, strain 13, stationary phase (50 $\mu \mathrm{g})$; 6 , strain $13-3, \log$ phase $(50 \mu \mathrm{g}) ; 7$, strain $13-3$, stationary phase $(50 \mu \mathrm{g})$. (B) Western blot analysis of a gel identical to that in panel A, except that lane 1 contained prestained markers. (C) Negative image of CBAH activity stain of proteins separated on nondenaturing polyacrylamide gels (1.5 mm; T, $7.5 \%$; C, $2.7 \%$ ). Lanes: 1 , NM522 (40 $\mu \mathrm{g}) ; 2$, NM522(pKLH-101) (40 $\mu \mathrm{g}) ; 3$, strain 13 (400 $\mu \mathrm{g}) ; 4$, strain 13-3 (400 $\mu \mathrm{g})$. (D) Western blot analysis of proteins separated as in panel C, except that the gel was $0.75 \mathrm{~mm}$ thick. Lanes: 1, NM522 (4 $\mu \mathrm{g}) ; 2$ and 3, NM522(pKLH-101) (lane 2, $2 \mu \mathrm{g}$; lane 3, $4 \mu \mathrm{g}$ ); 4 and 5, strain 13 (lane 4, $50 \mu \mathrm{g}$; lane 5, $100 \mu \mathrm{g}$ ); 6 and 7 , strain $13-3$ (lane $6,50 \mu \mathrm{g}$; lane $7,100 \mu \mathrm{g}$ ).

organisms were capable of hydrolyzing both glycine and taurine conjugates, while others preferred one or the other of the two classes. These observations served as an indication that there were a variety of CBAH enzymes in nature with distinct substrate-hydrolyzing capabilities. It also was known, from work by Nair and coworkers $(27,29,35)$ and more recently by Lundeen and Savage (19), that, even within a single strain of bacteria, there was a heterogeneity with respect to $\mathrm{CBAH}$ activities. C. perfringens ATCC 19574 was shown to produce several enzymes with distinct but overlapping $\mathrm{CBAH}$ activities against a variety of conjugated bile acid substrates. These enzymes also manifested differences with respect to one another in thermal stability (35). Despite the commercial use of extracts from $C$. perfringens for their CBAH activity, no concerted attempt has been made to purify and compare the individual components of this apparent mixture of activities. In the case of Lactobacillus sp. strain 100-100, at least four distinct CBAHs have been observed, each composed of different combinations of two separate polypeptides, $\alpha$ and $\beta$, in trimeric configuration (19).

We have been interested in elucidating the role that this group of enzymes plays in the gastrointestinal ecosystem and had focused on $C$. perfringens 13 as the model organism. This choice was based primarily on its utility for genetic studies because of the relative ease with which it could be transformed by electroporation (41). After being unsuccessful in attempts to identify a CBAH gene from $C$. perfringens genomic libraries with a DNA probe based on the N-terminal sequence of a CBAH purified by Gopal-Srivastava and Hylemon (11), we resorted to the indicator media method (7) used by Christiaens et al. (6). We were promptly successful in cloning a gene which encodes a protein product with $\mathrm{CBAH}$ activity. This gene and its product, upon nucleotide sequence analysis and product characterization, exhibited very little sequence or structural similarity to the enzyme purified from C. perfringens MCV 815 (11). However, the product is related at the sequence level to the previously described CBAH from L. plantarum (6), as well as to the penicillin V amidase from Bacillus sphaericus $(31,32)$. All three of these enzymes catalyze amide bond hydrolysis, all have optimal activity at an acidic $\mathrm{pH}$, and all are of similar size (ca. 37-kDa subunits with probably tetrameric native composition). Protein and nucleic acid database searches with these entire sequences or their highly conserved regions have not revealed other obvious members of this family. Other than inhibitor data suggesting the importance of a sulfhydryl group to catalytic activity (11), nothing is known of the enzymatic mechanism for any of these enzymes. Thus, it is difficult to even speculate on the location of active-site residues. 
The lack of homology of the CBAH gene from strain 13 with that previously purified from $C$. perfringens MCV 815 led us to examine strain 13 for additional CBAH activities. Using the enzymatic activity assay after fractionation of extracts by PAGE, we have shown that there is at least one additional CBAH activity in crude extracts of strain 13. The failure of this second activity to cross-react with antibody raised against CBAH-1, along with the presence of this second activity in mutant strains with a disrupted $\mathrm{CBAH}-1$ gene, indicates that this second enzyme is not a heteromultimer containing CBAH-1 subunits, as was the case with the multiple forms of CBAH observed in Lactobacillus sp. strain 100-100 (19). The observation that the CBAH from C. perfringens MCV 815 had a subunit size of $56 \mathrm{kDa}(11)$, along with its N-terminal sequence dissimilarity, leads to the possibility that it is derived from a different protein family from the penicillin amidase$\mathrm{CBAH}$ cluster. We are currently purifying and characterizing the second $\mathrm{CBAH}(\mathrm{CBAH}-2)$ from the strain 13 knockout mutant to determine its relationship to $\mathrm{CBAH}-1$.

\section{ACKNOWLEDGMENTS}

We thank Mason Smith and Carolyn Jones for preparation of antibodies, Mike Bennett for oligonucleotide synthesis, and Jeff Smith for helpful discussion and critical review of the manuscript.

\section{REFERENCES}

1. Archer, R. H., R. Chong, and I. S. Maddox. 1982. Hydrolysis of bile acid conjugates by Clostridium bifermentans. Eur. J. Appl. Microbiol. 14:41-45.

2. Ausubel, F. M., R. Brent, R. E. Kingston, D. D. Moore, J. G. Seidman, J. A. Smith, and K. Struhl (ed.). 1987. Current protocols in molecular biology. John Wiley \& Sons, Inc., New York.

3. Bagheri, S. A., M. G. Bolt, J. L. Boyers, and R. H. Palmer. 1978. Stimulation of thymidine incorporation in mouse liver and biliary tract epithelium by lithocholate and deoxycholate. Gastroenterology 74:188-192.

4. Bradford, M. M. 1976. A rapid and sensitive method for the quantitation of microgram quantities of protein utilizing the principles of protein-dye binding. Anal. Biochem. 72:248-254.

5. Catteau, M., M. Henry, and H. Beerens. 1971. Deconjugation of bile salts by bacteria of the genera Bacteroides and Bifidobacterium. Ann. Inst. Pasteur Lille 22:201-205. (In French.)

6. Christiaens, H., R. J. Leer, P. H. Pouwels, and W. Verstraete. 1992. Cloning and expression of a conjugated bile acid hydrolase gene from Lactobacillus plantarum by using a direct plate assay. Appl. Environ. Microbiol. 58:37923798.

7. Dashkevicz, M. P., and S. D. Feighner. 1989. Development of a differential medium for bile salt hydrolase-active Lactobacillus spp. Appl. Environ. Microbiol. 55:11-16.

8. Dietschy, J. M. 1974. Bile acids: their absorption from the gastrointestinal tract and role during fat absorption. Verh. Dtsch. Ges. Inn. Med. 80:399407

9. Drasar, B. S., M. J. Hill, and M. Shiner. 1966. The deconjugation of bile salts by human intestinal bacteria. Lancet 4:1237-1238.

10. Gilliland, S. E., and M. L. Speck. 1977. Deconjugation of bile acids by intestinal lactobacilli. Appl. Environ. Microbiol. 33:15-18.

11. Gopal-Srivastava, R., and P. B. Hylemon. 1988. Purification and characterization of bile salt hydrolase from Clostridium perfringens. J. Lipid Res. 29:1079-1085

12. Hill, M. J., and B. S. Drasar. 1968. Degradation of bile salts by human intestinal bacteria. Gut 9:22-27.

13. Hirano, S., N. Masuda, H. Oda, and H. Mukai. 1981. Transformation of bile acids by Clostridium perfringens. Appl. Environ. Microbiol. 42:394-399.

14. Kawamoto, K., I. Horibe, and K. Uchida. 1989. Purification and characterization of a new hydrolase for conjugated bile acids, chenodeoxycholyltaurine hydrolase, from Bacteroides vulgatus. J. Biochem. 106:1049-1053.

15. Laemmli, U. K. 1970. Cleavage of structural proteins during the assembly of the head of bacteriophage T4. Nature (London) 227:680-685.

16. Lee, Y. P., and T. Takahashi. 1966. An improved colorimetric determination of amino acids with the use of ninhydrin. Anal. Biochem. 14:71-77.

17. Lewis, R., and S. Gorbach. 1972. Modification of bile acids by intestinal bacteria. Arch. Intern. Med. 130:545-549.

18. Lundeen, S. G., and D. C. Savage. 1990. Characterization and purification of bile salt hydrolase from Lactobacillus sp. strain 100-100. J. Bacteriol. 172: $4171-4177$.
19. Lundeen, S. G., and D. C. Savage. 1992. Multiple forms of bile salt hydrolase from Lactobacillus sp. strain 100-100. J. Bacteriol. 174:7217-7220.

20. Mahony, D. E., C. E. Meier, I. A. Macdonald, and L. V. Holdeman. 1977. Bile salt degradation by nonfermentative clostridia. Appl. Environ. Microbiol. 34:419-423.

21. Maniatis, T., E. F. Fritsch, and J. Sambrook. 1982. Molecular cloning: laboratory manual. Cold Spring Harbor Laboratory, Cold Spring Harbor, N.Y.

22. Marmur, J. 1961. A procedure for the isolation of deoxyribonucleic acid from microorganisms. J. Mol. Biol. 3:208-218.

23. Masuda, N. 1981. Deconjugation of bile salts by Bacteroides and Clostridium. Microbiol. Immunol. 25:1-11.

24. Mitvedt, T. 1974. Microbial bile acid transformation. Am. J. Clin. Nutr 27:1341-1347.

25. Mitvedt, T., and A. Norman. 1967. Bile acid transformations by microbial strains belonging to genera found in intestinal contents. Acta Pathol. Microbiol. Scand. 71:629-638.

26. Mitvedt, T., and A. Norman. 1968. Anaerobic, bile acid transforming microorganisms in rat intestinal content. Acta Pathol. Microbiol. Scand. 72:337344

27. Nair, P. P., M. Gordon, S. Gordon, J. Reback, and A. I. Mendeloff. 1965. The cleavage of bile acid conjugates by cell-free extracts from Clostridium perfringens. Life Sci. 4:1887-1892.

28. Nair, P. P., M. Gordon, and J. Reback. 1967. The enzymatic cleavage of the carbon-nitrogen bond in 3-alpha, 7-alpha, 12-alpha-trihydroxy-5-betacholan-24-oylglycine. J. Biol. Chem. 242:7-11.

29. Nair, P. P., G. Kessie, and V. P. Flanagan. 1986. Reaffirmation of the validity of enzymatic cleavage of lithocholic acid from N-epsilon-lithocholyl-L-lysine and N-alpha-CBZ-N-epsilon-lithocholyl-L-lysine. J. Lipid Res. 27:905-909.

30. Narisawa, T., N. E. Magadia, J. H. Weisburger, and E. L. Wynder. 1974 Promoting effect of bile acids on colon carcinogenesis after intrarectal instillation of N-methyl- $\mathrm{N}^{\prime}$-nitro-N-nitrosoguanidine in rats. J. Natl. Cancer Inst. 53:1093-1097.

31. Olsson, A., T. Hagström, B. Nilsson, M. Uhlén, and S. Gatenbeck. 1985. Molecular cloning of Bacillus sphaericus penicillin V amidase gene and its expression in Escherichia coli and Bacillus subtilis. Appl. Environ. Microbiol. 49:1084-1089.

32. Olsson, A., and M. Uhlén. 1986. Sequencing and heterologous expression of the gene encoding penicillin V amidase from Bacillus sphaericus. Gene 45:175-181.

33. Owen, R. W. 1985. Biotransformation of bile acids by clostridia. J. Med Microbiol. 20:233-238.

34. Palmer, R. H. 1976. Toxic effects of lithocholate on the liver and biliary tree, p. 227-240. In W. Taylor (ed.), The hepatobiliary system. Fundamental and pathological mechanisms. Plenum Press, New York.

35. Patniak, R. N., M. Sokolow, M. Vocci, and P. P. Nair. 1975. Characterization of clostridial cholanoylamino acid hydrolase. Gastroenterology 68:966. (Abstract.)

36. Playoust, M. R., and K. J. Isselbacher. 1964. Studies on the transport and metabolism of conjugated bile salts by intestinal mucosa. J. Clin. Invest. 43:467-476

37. Reddy, B. S., J. H. Weisburger, and E. L. Wynder. 1978. Colon cancer: bile salts as tumor promoters, p. 453-464. In T. J. Slaga, A. Sivak, and R. K. Boutwell (ed.), Carcinogenesis. Mechanisms of Tumor Promotion and Cocarcinogenesis, vol. 2. Raven Press, New York

38. Roberts, I., W. M. Holmes, and P. B. Hylemon. 1988. Development of a new plasmid system for Escherichia coli and Clostridium perfringens. Appl. Environ. Microbiol. 54:268-270.

39. Sanger, F., S. Nicklen, and A. R. Coulson. 1977. DNA sequencing with chain-terminating inhibitors. Proc. Natl. Acad. Sci. USA 74:5463-5467.

40. Schiff, E. R., N. C. Small, and J. M. Dietschy. 1972. Characterization of the kinetics of the passive and active transport mechanisms for bile acid absorption in the small intestine and colon of the rat. J. Clin. Invest. 51:1351-1362.

41. Scott, P. T., and J. I. Rood. 1989. Electroporation-mediated transformation of lysostaphin-treated Clostridium perfringens. Gene 82:327-333.

42. Shimada, K., K. S. Bricknell, and S. M. Finegold. 1969. Deconjugation of bile acids by intestinal bacteria: review of literature and additional studies. J. Infect. Dis. 119:73-81.

43. Shindo, K., and K. Fukushima. 1976. Deconjugation of bile acids by human intestinal bacteria. Gastroenterol. Jpn. 11:167-174.

44. Stellwag, E. J., and P. B. Hylemon. 1976. Purification and characterization of bile salt hydrolase from Bacteroides fragilis subsp. fragilis. Biochim. Biophys. Acta 452:165-176.

45. Tannock, G. W., M. P. Dashkevicz, and S. D. Feighner. 1989. Lactobacill and bile salt hydrolase in the murine intestinal tract. Appl. Environ. Microbiol. 55:1848-1851.

46. Towbin, H., T. Staehelin, and J. Gordon. 1979. Electrophoretic transfer of proteins from polyacrylamide gels to nitrocellulose sheets: procedure and some applications. Proc. Natl. Acad. Sci. USA 76:4350-4354. 